\title{
A Comparative Study of Service Quality of Life Insurance Companies in India
}

\section{Neha Sharma, Santi SwarupKandikonda}

Research Scholar, Department of Management, Dayalbagh Educational Institute, Dayalbagh, Agra - 282 005, India.

Associate Professor, Department of Management, Dayalbagh Educational Institute, Dayalbagh, Agra - 282 005,

\section{Abstract} India.

The Indian Life Insurance sector has witnessed a major revamp in 1999 with the establishment of Insurance Regulatory and Development Authority (IRDA) and subsequent entry of Private sector players. These changes are affecting the way service is being delivered. Technology usage, new innovative product introduction and competition are seen as drivers of quality of service being provided to the customers.

In this study using SERVQUAL model, we have examined the importance of service based on the 5 dimensions viz, Tangibles, Reliability, Responsiveness, Assurance and Empathy. Using 120 Life Insurance policy holders from 3 Life insurance companies in Agra the study identified that the gaps exist even after 15 years of privatization of this sector. The study indicated that a lot needs to be done for improving customer focus and services activity in the Life Insurance sector. Regular customer surveys with increased sample sizes across the country will enable the Insurance companies to fill the gaps.

\section{Council for Innovative Research}

Peer Review Research Publishing System

\section{Journal of Social Science Research}

Vol.4, No.1

editor@jssronline.com

www.cirworld.com, www.jssronline.com

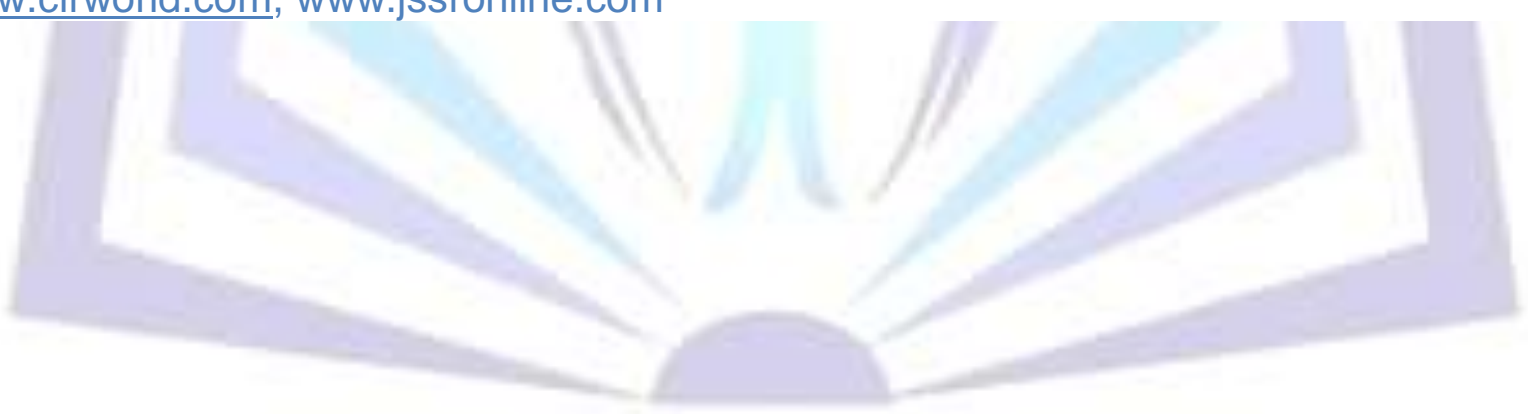




\subsection{Introduction}

Life insurance (or commonly life assurance, especially in the Commonwealth) is a contract between an insured (insurance policy holder) and an insurer or assurer, where the insurer promises to pay a designated beneficiary a sum of money (the "benefits") in exchange for a premium, upon the death of the insured person. Depending on the contract, other events such asterminal illness or critical illness may also trigger payment. The policy holder typically pays a premium, either regularly or as a lump sum.

Life Insurance in India was nationalized by incorporating Life Insurance Corporation (LIC) in 1956. All private life insurance companies at that time were taken over by LIC.In 1993, the Government of India appointed RN Malhotra Committee to lay down a road map for privatization of the life insurance sector. While the committee submitted its report in 1994, it took another six years before the enabling legislation was passed in the year 2000, legislation amending the Insurance Act of 1938 and legislating the Insurance Regulatory and Development Authority Act of 2000. The same year the newly appointed insurance regulator - Insurance Regulatory and Development Authority IRDA—started issuing licenses to private life insurers. Life Insurance is the fastest growing sector in India since 2000 as Government allowed Private players and FDI up to $26 \%$ and recently increased it to $49 \%$.

LIC had made Indian insurance industry a seller's market, where customer had no option other than to buy its (LIC's) product. LIC had also not tried to explore the market but were happy what they were getting effortlessly.LIC was synonymous with insurance in India and it had established an enviable brand image for itself, especially in the rural areas and small towns. However, with the entry of new players, the insurance market changed almost overnight. The private insurers seemed all set to make the industry marketing-driven, wherein technical and service excellence would be the key factors of success. The private companies, in a bid to make their presence felt and their brand noticed, initiated a series of aggressive marketing and promotion initiatives, something that buyers of insurance were not accustomed to.

Service quality is how well the service provided is meeting the expectation of customer who perceived it. That is, providing high-quality service as per the expected standards of customers resulting in satisfied customers (James et al., 1983). It is a perceived judgment, resulting from an evaluation process where customers compare their expectations with the service they perceive which they have received (Gr"onroos, 1984). However, due to the unique features of service such as performance-oriented, intangible, heterogeneous, inseparable, and perishable. It is difficult not only to measure service quality, but also to provide the same quality of services to all customers. The gap model (Paraguayan,Zeithami and Berry ,1985) was identified to address this problem.

\subsection{The Customer Service Gap Model}

SERVQUAL (service quality gap model) is a gap method in service quality measurement, a tool that can be used by Product Manager across all industries. The aim of this model is to:

Identify the gaps between customer expectation and the actual services provided at different stages of service delivery Close the gap and improve the customer service

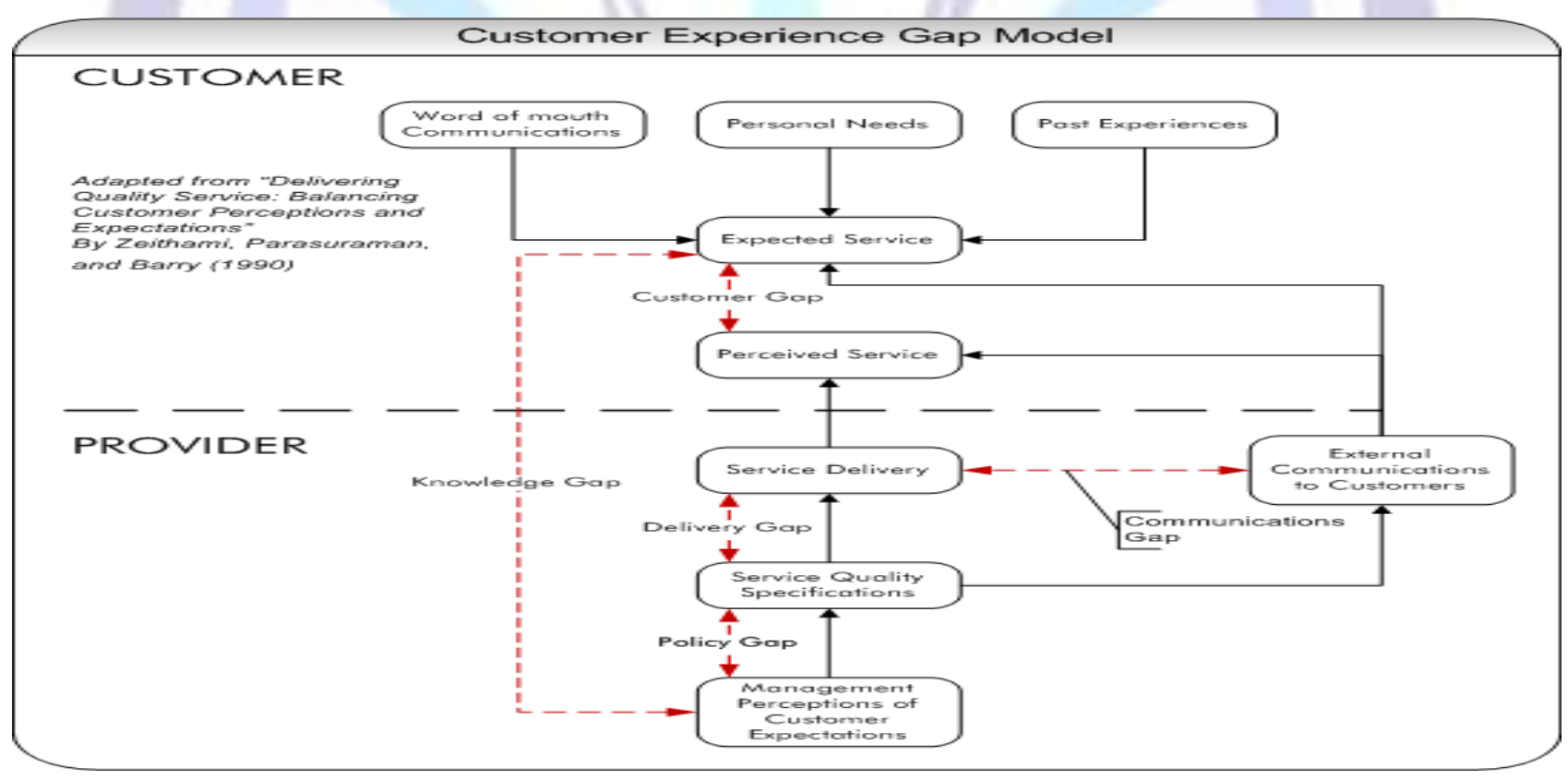

Service quality Gap model.

Source: http://www.brainmates.com.au/brainrants/the-customer-service-gap-model 
- GAP 1: Gap between consumer expectation and management perception: arises when the management or service provider does not correctly perceive what the customers wants or needs.

- GAP 2: Gap between management perception and service quality specification: this is when the management or service provider might correctly perceive what the customer wants, but may not set a performance standard.

- GAP 3: Gap between service quality specification and service delivery: may arise pertaining to the service personnel. This could arise due to there being poor training, incapability or unwillingness to meet the set service standard.

- GAP 4: Gap between service delivery and external communication: consumer expectations are highly influenced by statements made by company representativesand advertisements. The gap arises when these assumed expectations are not fulfilled at the time of service delivery.

- GAP 5: Gap between expected service and experienced service: this gap arises when the consumer misinterprets the service quality.

Among the most popular assessments tools of service quality is SERVQUAL, an instrument designed by the marketing research team of Berry, Paraguayan, and Zenithal (PB\&Z). Through numerous qualitative studies, they evolved a set of five dimensions which have been consistently ranked by customers to be most important for service quality, regardless of service industry.

These dimensions are defined as follows:

Tangibles appearance of physical facilities, equipment, personnel, and communication materials; Reliability ability to perform the promised service dependably and accurately; Responsiveness willingness to help customers and provide prompt service; Assurance knowledge and courtesy of employees and their ability to convey trust and confidence; Empathy the caring, individualized attention the firm provides its customers.

\subsection{Existing Literature Review}

Jiang, James J., Klein, Gary; Crampton, Suzanne M (2000) examined theSERVQUAL instrument as a possible measure to assist managers and researchers in evaluating service quality. They also examined the appropriateness of the SERVQUAL measure, a large industry sample serves to verify the anticipated structure of the instrument .Moreover,SERVQUAL instrument can serve as a useful indicator for information system managers attempting to identify areas of needed service improvement.

Sureshchandar G.S.; Rajendran C. Anantharaman R.N (2002)examined the critical determinants of service quality that have been overlooked in the literature and proposes a comprehensive model. It has been designed with specific reference to the banking sector. The proposed instrument has been empirically tested for unidimensionality, reliability and construct validity.Moreover study offered a systamatic procedure that could from the cornerstone for providing further insights on the conceptual and empirical comprehension of customer perceived service quality and its constituents.

Tiffany K.P. Lam (2002) studied on items of SERVQUAL. Factor analysis established the existence of six service dimensions, which is different from the original findings of Paraguayan et al. (1988). The new solution thus requires considerably different interpretations.

Ahuja, Rajeev (2003) has pointed out that, in developing countries market structure and government intervention in the insurance market has greater importance than in the developed countries.

MaiveSuuroja (2003) analyzed the main debates about how to conceptualize service quality-about the nature of perceived service quality and the formation of service quality. Moreover paper explored the theoretical viewpoints and seeks supportive empirical evidence.

Pathak and Dhar (2003) have identified four factors as important in terms of choice of insurance provider. These are customer orientation, incentives offered to customers, reliability and range of services foreign collaboration and ease of documentation.

Leugenia Ham and Steven Hayduk (2004) founded that several implications for higher educational institutions, managers, and leaders of decision-making processes throughout the world. Service quality, customer satisfaction, and behavioral intentions are global issues that affect all organizations, large or small, profit or non-profit, global or local. They are all influenced or discouraged, satisfied or dissatisfied with positive loyalty behavioral intentions or negative complaining reactions, propelled by the level of service quality received.

Mohammed Alamgir and Mohammad Shamsuddoha (2004) studied the various literature on Service quality dimensions to adapt perfect strategy and policy for service oriented organizations, especially in the banking setor.It identified the relative importance of service quality dimensions analysis.Moreover it fully focused on service quality issues, will help to understand service dimensions issues for an organization.

RossanoGiandomenico (2006) showed that the effective liabilities duration of an Insurance company exposed to the default-risk is different from the duration of a default-free zero coupon bond with the same time of maturity. It also showed the value of equity can be immunized in a dynamic way with respect to the movement of the spot-rate by selling and purchasing the default-free bonds in the firm asset. Moreover it consider the surrender option and the mortally issue such that it corrects some pitfalls that are commonly encountered in the insurance industry.

David Yap, Greg Timbrell, Guy G. Gable, Taizan Chan (2007) presented the results from cross-referencing seven service quality measurement models from seven different industries, with SERVQUAL.the results indicate that 'assurance' and

449 | P a g e 
'empathy' dimensions are represented across all seven industries, while other attributes in the various industryinstruments either map partially or did not map onto SERVQUAL's (1988) five dimensions.

Rainer Gob, Christopher McCollin and Maria Fernanda Ramalhoto (2007) suggested an ordinal interpretation of Likert scales, attitude survey data are often evaluated with techniques designed for cardinal measurements. The paper discussed the interpretation of scales for attitude measuring and gives a survey of data analysis techniques under the proper ordinal understanding.

Jos Van Iwaarden and Ton Van der Wiele (2007) studied what quality factors are perceived as important in relation to their use of web sites. The results of the questionnaire survey are analysed in relation to the five service quality (SERVQUAL) dimensions (tangibles; reliability; responsiveness; assurance; empathy) as developed by Zenithal et al.

Sonia Chawla and Fulbag Singh (2008) identified the service quality factors affecting customer satisfaction levels of the policyholders. Study is based on responses of 210 policyholders from northern India. Reliability analysis and factor analysis have been carried out to test data that was collected through survey method. Finding reveals that accessibility factor has a higher mean satisfaction as compared to mean satisfaction of reliability and assurance factors. Comparison of overall mean satisfaction based on various factors extracted, showed that respondents who had purchased insurance policies before privatization, had a higher mean score as compared to the respondents who took insurance policies after privatization.

Martina Eckardt and SolvigRathke (2008) studied that Insurance Intermediaries help consumers to economize on information and transaction costs in insurance market and it provide heterogeneous services, which are difficult to assess by incompletely informed consumers. By performing OLS estimations they test the impact of the different distribution channels, but also of other factors relating to the information processing activities on intermediaries service quality. Atlast they found that service quality depends also to a large extent on the information gathering and processing activities of the individual intermediaries.

Sunaynakhurana (2008) tried to understand consumer behavior in the insurance sector.The paper identified customer preferences regarding plans and company, their purpose of buying insurance policies their satisfaction level and their future plans for new insurance policy.

Erdogan H. Ekiz and Ali Bavik(2008) aimed to provide an example for developing a measurement scale by using car rental services as a case.They used both qualitative and quantitative methods in three fundamental stage recommended by Churchill (1979) and Paraguayan, Zenithal\& Berry (1988).The paper also introduced the setting of the research and presents need for scale development briefly which is followed by discussion, implications and limitations.

Saif Siddiqui (2009) studied the history of Life Insurance dates back to the year 1818. This paper produces an overview of present position of Life Insurance Sector in India and study various economic indicators related to all Life insurance Companies operating in India.

PandelisZisis, AlexandrosGarefalakisand Nikolaos Sariannidis(2009) aimed to provide the reader with an in-depth insight of the integration of performance measurement in the assessment and improvement of service quality. Moreover the paper conducted under qualitative principles as well as documentary data were collected. Finally, questionnaires were applied to the company's key customers, presenting a more accurate insight of the improvement of performance indicators in service quality context.

C.N. Krishna Naik , SwapnaBhargaviGantasala and Gantasala V. Prabhakar(2010)analysed the gap between perceptions and expectations of the customer, concerning with the service at retail units in the South Indian state of Andhra Pradesh. Its main purpose is to describe applied of service quality (servqual) dimension in retail Business (2) to know service quality (servqual) dimensions that make customers satisfied, and (3) to know service quality (servqual) dimensions that are dominant in influencing customer satisfaction.

Niveen El Saghier, Demyana Nathan (2013) studied was based questionnaire survey which was conducted in Egypt. The paper used empirical research to analyze service quality of banking services provided by banks in Egypt.

\subsection{Research Methodology}

We have applied the Servqual model to analyze gaps between expected and perceived service offered.Primary data using questionnaire was collected by conducting a survey. The Companies that were selected for the study are LIC, SBI Life Insurance and HDFC Standard Life Insurance. The questionnaire was administered to Life insurance Policy holders of companies. A total sample of 120 respondents 40 from each company mentioned above from Agra region were selected using Purposive sampling.Their responses were recorded and mean scores were analyzed using Z-test for identifying the significant differences between expected and Perceived service equality scores. The data was collected using questionnaire (Annexure). Expected and perceived scores for each service for the three companies were first calculated. Using SPSS software the difference between the expected perceived services was analyzed using $Z$ test. The results indicated either a significant or insignificant difference between expected and perceived quality of the services offered.

\subsection{Analysis}

The analysis is done by calculating mean scores of perceived and expected service values and findings the significant difference exists between them.

5.1 The table given below gave the means perceived and expected value respectively for the factors as shown in table below: 


\section{LIC}

\begin{tabular}{|c|c|c|c|c|c|}
\hline & & Mean & $N$ & Std. Deviation & $\begin{array}{l}\text { Std.Error } \\
\text { Mean }\end{array}$ \\
\hline \multirow{2}{*}{ Pair 1} & lavout & 3.6750 & 40 & .76418 & .12083 \\
\hline & layout1 & 3.8500 & 40 & .69982 & .11065 \\
\hline \multirow{2}{*}{ Pair 2} & visually & 3.8500 & 40 & .53349 & .08435 \\
\hline & Visually1 & 3.9250 & 40 & .85896 & .13581 \\
\hline \multirow[t]{2}{*}{ Pair 3} & grooming & 3.9000 & 40 & .87119 & .13775 \\
\hline & grooming 1 & 4.0250 & 40 & .83166 & .13150 \\
\hline \multirow[t]{2}{*}{ Pair 4} & Time & 3.8750 & 40 & .72280 & .11428 \\
\hline & Time1 & 3.8500 & 40 & .89299 & .14119 \\
\hline \multirow[t]{2}{*}{ Pair 5} & interest & 3.8750 & 40 & .75744 & .11976 \\
\hline & Interest 1 & 4.1500 & 40 & .73554 & .11630 \\
\hline \multirow[t]{2}{*}{ Pair 6} & first & 3.8500 & 40 & .69982 & .11065 \\
\hline & first 1 & 3.9250 & 40 & .72986 & .11540 \\
\hline \multirow{2}{*}{ Pair 7} & services & 3.8750 & 40 & .82236 & .13003 \\
\hline & services 1 & 4.3000 & 40 & .68687 & .10860 \\
\hline \multirow[t]{2}{*}{ Pair 8} & prompt & 4.0000 & 40 & .75107 & .11875 \\
\hline & prompt 1 & 3.9000 & 40 & .77790 & .12300 \\
\hline \multirow[t]{2}{*}{ Pair 9} & busy & 3.7250 & 40 & .55412 & .08761 \\
\hline & busyl & 4.1250 & 40 & .79057 & .12500 \\
\hline \multirow{2}{*}{$\begin{array}{l}\text { Pair } \\
10\end{array}$} & confidence & 4.1000 & 40 & .70892 & .11209 \\
\hline & confidencel & 4.0000 & 40 & .84732 & .13397 \\
\hline \multirow{2}{*}{$\begin{array}{l}\text { Pair } \\
11\end{array}$} & safety & 3.9250 & 40 & .72986 & .11540 \\
\hline & safety 1 & 4.0000 & 40 & .78446 & .12403 \\
\hline \multirow{2}{*}{ Pair } & courtesy & 3.9750 & 40 & .80024 & .12653 \\
\hline & courtesy 1 & 4.0250 & 40 & .65974 & .10431 \\
\hline \multirow{2}{*}{$\begin{array}{l}\text { Pair } \\
13\end{array}$} & attention & 3.8500 & 40 & .80224 & .12685 \\
\hline & attention 1 & 4.1500 & 40 & .76962 & .12169 \\
\hline \multirow{2}{*}{ Pair } & convenient & 3.9750 & 40 & .57679 & .09120 \\
\hline & convenient 1 & 3.9750 & 40 & .76753 & .12136 \\
\hline \multirow{2}{*}{$\begin{array}{l}\text { Pair } \\
15\end{array}$} & Needs & 3.9500 & 40 & .67748 & $.10>12$ \\
\hline & Needs1 & 4.0000 & 40 & .81650 & .12910 \\
\hline
\end{tabular}

Using $\mathrm{Z}$-test the significance of the difference between expected and perceived service quality was analysed in the table given below for the LIC policy holders investors of insurance company.

Table 5.2

\section{Paired Sample Test}

\begin{tabular}{|c|c|c|c|c|c|c|c|c|c|}
\hline & \multicolumn{5}{|c|}{ Paired Differences } & \multirow[b]{3}{*}{$z$} & \multirow{3}{*}{$\begin{array}{l}\text { Sig } \\
\text { (2tailed) } \\
\end{array}$} & \multirow[b]{3}{*}{ Sig/N.sig } \\
\hline & & \multirow[b]{2}{*}{ Mean } & \multirow{2}{*}{$\begin{array}{l}\text { Std. } \\
\text { Deviation }\end{array}$} & \multirow{2}{*}{$\begin{array}{l}\text { Std. } \\
\text { Error } \\
\text { Mean } \\
\end{array}$} & \multicolumn{2}{|c|}{$\begin{array}{l}95 \% \text { Confidence } \\
\text { Interval of the } \\
\text { Difference }\end{array}$} & & & \\
\hline & & & & & Lower & Upper & & & \\
\hline Pair 1 & lauout - layout1 & -.17500 & 1.08338 & .17130 & -.52148 & 17148 & -1.022 & .313 & sia \\
\hline Pair 2 & visually - visually 1 & -.07500 & .94428 & .14930 & -.37700 & .22700 & -.502 & .618 & Sig \\
\hline Pair 3 & $\begin{array}{l}\text { grooming } \\
\text { grooming1 }\end{array}$ & -.12500 & 1.11373 & .17610 & -.48119 & .23119 & -.710 & .482 & sig \\
\hline Pair 4 & Time - Time1 & .02500 & 1.22971 & .19443 & -.36828 & .41828 & .129 & .898 & sia \\
\hline $\begin{array}{l}\text { Pair } 5 \\
\text { Pair } 6\end{array}$ & $\begin{array}{l}\text { Interest - Interest1 } \\
\text { first - first1 }\end{array}$ & $\begin{array}{l}-.27500 \\
-.07500\end{array}$ & $\begin{array}{l}1.10911 \\
1.07148\end{array}$ & $\begin{array}{l}.17537 \\
.16942\end{array}$ & $\begin{array}{l}-.62971 \\
-.41768\end{array}$ & $\begin{array}{l}.07971 \\
.26768\end{array}$ & $\begin{array}{l}-1.568 \\
-.443\end{array}$ & $\begin{array}{l}.125 \\
.660\end{array}$ & $\begin{array}{l}\text { sig } \\
\text { sig }\end{array}$ \\
\hline Pair 7 & services - services 1 & -.42500 & 1.00989 & .15968 & -.74798 & -.10202 & -2.662 & .011 & \\
\hline $\begin{array}{l}\text { Pair } 8 \\
\text { Pair } 9\end{array}$ & $\begin{array}{l}\text { prompt - prompt1 } \\
\text { busy - busy } 1\end{array}$ & $\begin{array}{l}.10000 \\
-.40000\end{array}$ & $\begin{array}{l}1.10477 \\
.84124\end{array}$ & $\begin{array}{l}.17468 \\
.13301\end{array}$ & $\begin{array}{l}-.25332 \\
-.66904\end{array}$ & $\begin{array}{l}.45332 \\
-.13096\end{array}$ & $\begin{array}{l}.572 \\
-3.007\end{array}$ & $\begin{array}{l}.570 \\
.005\end{array}$ & $\begin{array}{l}\text { sig } \\
\text { N. sig }\end{array}$ \\
\hline $\begin{array}{l}\text { Pair } \\
10\end{array}$ & $\begin{array}{l}\text { confidence } \\
\text { confidence1 }\end{array}$ & .10000 & 1.12774 & .17831 & -.26067 & .46067 & .561 & .578 & \\
\hline $\begin{array}{l}\text { Pair } \\
11\end{array}$ & safety - safety 1 & -.07500 & 1.04728 & .16559 & -.40994 & .25994 & -.453 & .653 & N.sig \\
\hline $\begin{array}{l}\text { Pair } \\
12\end{array}$ & courtesy - courtesy 1 & -.05000 & 1.06096 & .16775 & -.38931 & .28931 & -.298 & .767 & N.sig \\
\hline $\begin{array}{l}\text { Pair } \\
13\end{array}$ & attention - attention 1 & -.30000 & 1.20256 & .19014 & -.68460 & .08460 & -1.578 & .123 & sig \\
\hline $\begin{array}{l}\text { Pair } \\
14\end{array}$ & $\begin{array}{l}\text { convenient } \\
\text { convenient1 }\end{array}$ & .00000 & .87706 & .13868 & -.28050 & .28050 & .000 & 1.000 & sig \\
\hline $\begin{array}{l}\text { Pair } \\
15\end{array}$ & Needs - Needs1 & -.05000 & 1.15359 & .18240 & -.41894 & .31894 & -.274 & .785 & N.sig \\
\hline
\end{tabular}


Paired sample test was done. There were 40 respondent from each company mentioned above from Agra region were selected using Purposive sampling. Their responses were recorded and mean scores were analyzed using Z-test for identifying the significant differences between expected and Perceived service quality scores. The data was collected using questionnaire (Annexure). Expected and perceived scores for each service for the three companies were first calculated. Using SPSS software the difference between the expected perceived services was analyzed using $Z$ test. The results indicated either a significant or insignificant difference between expected and perceived quality of the services offered.

Table 5.3

Paired Samples Statistics

\begin{tabular}{|ll|r|r|r|r|}
\hline & & & & & Std. Error \\
& & Mean & $\mathrm{N}$ & Std. Deviation & \\
\hline Pair 1 & layout & 3.9250 & 40 & .72986 & .11540 \\
& layout2 & 4.0000 & 40 & .75107 & .11875 \\
Pair 2 & visually & 3.7750 & 40 & .73336 & .11595 \\
& visually2 & 3.7250 & 40 & .84694 & .13391 \\
Pair 3 & grooming & 3.8750 & 40 & .88252 & .13954 \\
& grooming2 & 3.7500 & 40 & .92681 & .14654 \\
Pair 4 & time & 3.8500 & 40 & .76962 & .12169 \\
& time2 & 3.8500 & 40 & .80224 & .12685 \\
Pair 5 & Interest & 3.9750 & .83166 & .13150 \\
& Interest2 & 3.9250 & 40 & .79703 & .12602 \\
Pair 6 & first & 4.0250 & 40 & .80024 & .12653 \\
& first2 & 3.9000 & 40 & .84124 & .13301 \\
Pair 7 & services & 3.8750 & 40 & .79057 & .12500 \\
& services2 & 3.8250 & 40 & .84391 & .13343 \\
Pair 8 & prompt & 4.0250 & 40 & .73336 & .11595 \\
& prompt2 & 3.9250 & 40 & .82858 & .13101 \\
Pair 9 & busy & 4.0750 & 40 & .61550 & .09732 \\
& busy2 & 3.8500 & .70 & .76962 & .12169 \\
Pair 10 & confidence & 4.1250 & 40 & .75744 & .11976 \\
& confidence2 & 4.0500 & 40 & .63851 & .10096 \\
Pair 11 & safety & 3.9500 & 40 & .71432 & .11294 \\
& safety2 & 3.9500 & 40 & .84580 & .13373 \\
Pair 12 & courtesy & 3.9500 & 40 & .67748 & .10712 \\
& courtesy2 & 3.9750 & 40 & .65974 & .10431 \\
Pair 13 & attention & 3.9500 & 40 & .63851 & .10096 \\
& attention2 & 4.0500 & 40 & .74936 & .11848 \\
Pair 14 & convenient & 3.9750 & 40 & .12653 \\
& convenient2 & 3.9250 & 40 & .59024 & .12602 \\
Pair 15 & Needs & 4.0750 & 40 & .12083 \\
& Needs2 & 4.0000 & 40 & .09473 \\
\hline
\end{tabular}

Using $Z$-test the significance of the difference between expected and perceived service quality was analysed in the table given below for the LIC policy holders investors of insurance company. 
Table 5.4

Paired Samples Test

\begin{tabular}{|c|c|c|c|c|c|c|c|c|c|}
\hline & \multicolumn{5}{|c|}{ Paired Differences } & \multirow[b]{3}{*}{$z$} & \multirow{3}{*}{$\begin{array}{l}\text { Sig.(2 } \\
\text { talied ) }\end{array}$} & \multirow[b]{3}{*}{ Sig/n.sig } \\
\hline & & \multirow[b]{2}{*}{ Mean } & \multirow{2}{*}{$\begin{array}{l}\text { Std. } \\
\text { Deviation }\end{array}$} & \multirow{2}{*}{$\begin{array}{l}\text { Std. Error } \\
\text { Mean }\end{array}$} & \multicolumn{2}{|c|}{\begin{tabular}{lrr}
$95 \%$ & \multicolumn{2}{c}{ Confidence } \\
Interval of the \\
Difference
\end{tabular}} & & & \\
\hline & & & & & Lower & Upper & & & \\
\hline Pair 1 & layout - layout2 & -.07500 & 1.16327 & .18393 & -.44703 & .29703 & -.408 & .686 & N.sig \\
\hline Pair 2 & visually - visually2 & .05000 & 1.06096 & .16775 & -.28931 & .38931 & 298 & .767 & N.sig \\
\hline Pair 3 & grooming - grooming2 & .12500 & 1.34331 & .21240 & -.30461 & .55461 & .589 & .560 & N.sig \\
\hline Pair 4 & time - time2 & .00000 & 1.06217 & .16794 & -.33970 & .33970 & .000 & 1.000 & sig \\
\hline Pair 5 & Interest - Interest2 & .05000 & 1.06096 & .16775 & -.28931 & .38931 & .298 & .767 & N.sig \\
\hline Pair 6 & first - first2 & .12500 & 1.22344 & .19344 & -.26627 & .51627 & .646 & .522 & N.sig \\
\hline Pair 7 & services - services2 & .05000 & 1.19722 & .18930 & -.33289 & .43289 & .264 & .793 & N.sig \\
\hline Pair 8 & prompt - prompt2 & .10000 & 1.08131 & .17097 & -.24582 & .44582 & .585 & .562 & N.sig \\
\hline Pair 9 & busy - busy2 & .22500 & 1.04973 & .16598 & -.11072 & .56072 & 1.356 & .183 & sig \\
\hline Pair 10 & $\begin{array}{l}\text { confidence } \\
\text { confidence2 }\end{array}$ & .07500 & 1.02250 & .16167 & -.25201 & .40201 & .464 & .645 & N.sig \\
\hline Pair 11 & safety - safety2 & .00000 & 1.15470 & .18257 & -.36929 & .36929 & .000 & 1.000 & sig \\
\hline Pair 12 & courtesy - courtesy2 & -.02500 & 1.07387 & .16979 & -.36844 & .31844 & -.147 & .884 & N.sig \\
\hline Pair 13 & attention - attention2 & -.10000 & 1.03280 & .16330 & -.43030 & .23030 & -.612 & .544 & N.sig \\
\hline Pair 14 & $\begin{array}{l}\text { convenient } \\
\text { convenient2 }\end{array}$ & .05000 & 1.03651 & .16389 & -.28149 & .38149 & .305 & .762 & N.sig \\
\hline Pair 15 & Needs - Needs2 & .07500 & .97106 & .15354 & -.23556 & .38556 & .488 & .628 & N.sig \\
\hline
\end{tabular}

Paired sample test was done .There were 40 respondent from each company mentioned above from Agra region were selected using Purposive sampling. Their responses were recorded and mean scores were analyzed using Z-test for identifying the significant differences between expected and Perceived service quality scores. The data was collected using questionnaire (Annexure). Expected and perceived scores for each service for the three companies were first calculated. Using SPSS software the difference between the expected perceived services was analyzed using $Z$ test. The results indicated either a significant or insignificant difference between expected and perceived quality of the services offered. 
Table 5.5

Paired Sample Test

\begin{tabular}{|ll|r|r|r|r|}
\hline & & & & Std. Error \\
& & Mean & $\mathrm{N}$ & Std. Deviation & \multicolumn{1}{c|}{ Mean } \\
\hline Pair 1 & layout & 3.6750 & 40 & .72986 & .11540 \\
& layout3 & 3.9750 & 40 & .73336 & .11595 \\
Pair 2 & visually & 3.9250 & 40 & .52563 & .08311 \\
& visually3 & 3.8750 & 40 & .64798 & .10245 \\
Pair 3 & grooming & 3.9750 & 40 & .89120 & .14091 \\
& grooming3 & 4.0500 & 40 & .90441 & .14300 \\
Pair 4 & time & 3.9500 & 40 & .78283 & .12378 \\
& time3 & 4.0000 & 40 & .75107 & .11875 \\
Pair 5 & Interest & 3.8750 & 40 & .82236 & .13003 \\
& Interest3 & 3.9250 & 40 & .85896 & .13581 \\
Pair 6 & first & 3.8750 & 40 & .64798 & .10245 \\
& first3 & 4.1000 & 40 & .67178 & .10622 \\
Pair 7 & services & 3.9750 & 40 & .94699 & .14973 \\
& services3 & 4.1000 & 40 & .92819 & .14676 \\
Pair 8 & prompt & 4.1000 & 40 & .74421 & .11767 \\
& prompt3 & 4.0250 & 40 & .76753 & .12136 \\
Pair 9 & busy & 3.7500 & .8935 \\
& busy3 & 3.8750 & 40 & .49355 & .07804 \\
Pair 10 & confidence & 4.1500 & 40 & .64798 & .10245 \\
& confidence3 & 4.1750 & 40 & .69982 & .11065 \\
Pair 11 & safety & 3.9500 & 40 & .71208 & .11259 \\
& safety3 & 3.9000 & 40 & .84580 & .13373 \\
Pair 12 & courtesy & 3.9750 & 40 & .77790 & .12300 \\
& courtesy3 & 4.0250 & 40 & .76753 & .12136 \\
Pair 13 & attention & 4.0000 & 40 & .89120 & .14091 \\
& attention3 & 3.7250 & 40 & .84732 & .13397 \\
Pair 14 & convenient & 3.9000 & 40 & .75064 & .11869 \\
& Convinient3 & 3.7250 & 40 & .54538 & .08623 \\
Pair 15 & Needs & 4.0000 & .96044 & .15186 \\
& Needs3 & 3.8250 & .78446 & .12403 \\
& & & .78078 & .12345 \\
& & & & \\
\hline
\end{tabular}

Using $Z$-test the significance of the difference between expected and perceived service quality was analysed in the table given below for the LIC policy holders investors of insurance company. 
Table 5.6

Paired Sample Test

\begin{tabular}{|c|c|c|c|c|c|c|c|c|c|}
\hline & \multicolumn{5}{|c|}{ Paired Differences } & \multirow[b]{3}{*}{$\mathbf{Z}$} & \multirow[b]{3}{*}{$\begin{array}{l}\text { Sig. (2 } \\
\text { talied) }\end{array}$} & \multirow[b]{3}{*}{ Sig/Nsig } \\
\hline & & \multirow[b]{2}{*}{ Mean } & \multirow{2}{*}{$\begin{array}{c}\text { Std. } \\
\text { Deviatio } \\
\mathbf{n} \\
\end{array}$} & \multirow{2}{*}{$\begin{array}{l}\text { Std. } \\
\text { Error } \\
\text { Mean } \\
\end{array}$} & \multicolumn{2}{|c|}{$\begin{array}{c}95 \% \\
\text { Confidence } \\
\text { Interval of the } \\
\text { Difference }\end{array}$} & & & \\
\hline & & & & & $\begin{array}{c}\text { Lowe } \\
\mathbf{r}\end{array}$ & Upper & & & \\
\hline $\begin{array}{l}\text { Pair } \\
1\end{array}$ & layout - layout3 & $\begin{array}{r}- \\
.30000\end{array}$ & .99228 & .15689 & 61735 & .01735 & -1.912 & .063 & sig \\
\hline $\begin{array}{l}\text { Pair } \\
2\end{array}$ & $\begin{array}{l}\text { visually - } \\
\text { visually3 }\end{array}$ & .05000 & .87560 & .13844 & .23003 & .33003 & .361 & .720 & $\operatorname{sig}^{N .}$ \\
\hline $\begin{array}{l}\text { Pair } \\
3\end{array}$ & $\begin{array}{l}\text { grooming - } \\
\text { grooming3 }\end{array}$ & $\begin{array}{r}- \\
.07500\end{array}$ & 1.32795 & .20997 & $\begin{array}{r}- \\
.49970\end{array}$ & .34970 & -.357 & .723 & $\mathrm{~N}$ \\
\hline $\begin{array}{l}\text { Pair } \\
4\end{array}$ & time - time 3 & $\begin{array}{r}- \\
.05000\end{array}$ & 1.06096 & .16775 & - & .28931 & -.298 & .767 & $\operatorname{sig}^{\mathrm{N} .}$ \\
\hline $\begin{array}{l}\text { Pair } \\
5\end{array}$ & $\begin{array}{l}\text { Interest - } \\
\text { Interest3 }\end{array}$ & $.05000^{-}$ & 1.15359 & .18240 & $\begin{array}{r}- \\
.41894^{-}\end{array}$ & .31894 & -.274 & .785 & $\mathrm{~N}$ \\
\hline $\begin{array}{l}\text { Pair } \\
6\end{array}$ & first - first 3 & $.22500^{-}$ & .80024 & .12653 & .48093 & .03093 & -1.778 & .083 & $\operatorname{sig}^{\mathrm{N} .}$ \\
\hline $\begin{array}{l}\text { Pair } \\
7\end{array}$ & $\begin{array}{l}\text { services - } \\
\text { services3 }\end{array}$ & $\begin{array}{r}- \\
.12500\end{array}$ & 1.38096 & .21835 & $\begin{array}{r}- \\
.56665\end{array}$ & .31665 & -.572 & .570 & sig $N$ \\
\hline $\begin{array}{l}\text { Pair } \\
8\end{array}$ & $\begin{array}{l}\text { prompt - } \\
\text { prompt3 }\end{array}$ & .07500 & 1.20655 & 19077 & .31087 & .46087 & .393 & .696 & $\begin{array}{ll} & \text { N. } \\
\text { sig }\end{array}$ \\
\hline $\begin{array}{l}\text { Pair } \\
9\end{array}$ & busy - busy 3 & $\begin{array}{r}- \\
.12500^{-}\end{array}$ & .88252 & .13954 & .40724 & .15724 & -.896 & .376 & sig \\
\hline $\begin{array}{l}\text { Pair } \\
10\end{array}$ & $\begin{array}{l}\text { confidence - } \\
\text { confidence } 3\end{array}$ & $\begin{array}{r}- \\
.02500\end{array}$ & .99968 & .15806 & $\begin{array}{r}- \\
.34471\end{array}$ & .29471 & -.158 & .875 & sig \\
\hline $\begin{array}{l}\text { Pair } \\
11\end{array}$ & safety - safety3 & .05000 & 1.21845 & .19265 & $\begin{array}{r}- \\
.33968\end{array}$ & .43968 & .260 & .797 & sig \\
\hline $\begin{array}{l}\text { Pair } \\
12\end{array}$ & $\begin{array}{l}\text { courtesy - } \\
\text { courtesy3 }\end{array}$ & $.05000^{-}$ & 1.21845 & .19265 & $\begin{array}{r}- \\
.43968\end{array}$ & .33968 & -.260 & .797 & sig \\
\hline $\begin{array}{l}\text { Pair } \\
13\end{array}$ & $\begin{array}{l}\text { attention - } \\
\text { attention3 }\end{array}$ & .27500 & 1.21924 & .19278 & .11493 & .66493 & 1.427 & .162 & sig \\
\hline $\begin{array}{l}\text { Pair } \\
14\end{array}$ & $\begin{array}{l}\text { convenient - } \\
\text { Convinient } 3\end{array}$ & .17500 & 1.00989 & .15968 & $\begin{array}{r}- \\
.14798\end{array}$ & .49798 & 1.096 & .280 & Sig \\
\hline $\begin{array}{l}\text { Pair } \\
15\end{array}$ & Needs - Needs 3 & .17500 & 1.00989 & .15968 & $\begin{array}{r}- \\
.14798\end{array}$ & .49798 & 1.096 & .280 & sig \\
\hline
\end{tabular}

Paired sample test was done. There were 40 respondent from each company mentioned above from Agra region were selected using Purposive sampling. Their responses were recorded and mean scores were analyzed using Z-test for identifying the significant differences between expected and Perceived service quality scores. The data was collected using questionnaire (Annexure). Expected and perceived scores for each service for the three companies were first calculated. Using SPSS software the difference between the expected perceived services was analyzed using $Z$ test. The results indicated either a significant or insignificant difference between expected and perceived quality of the services offered. 


\subsection{Conclusion}

Even though competition has increased in the Insurance sector with the opening of the sector, the gaps between the perceived and expected services still exist. While there could be improvement in service levels due to increased competition, it appears that the expectations of service also started increasing. We have taken investors of 3 Life insurance companies. We have studied the perceptions based on SERVQUAL model for a sample of 40 investors. The results indicate significant differences in LIC policy holders perceived and expected scores related to layout,visually appealing, time taken to provide service, interest shown in customers, Prompt service, Confident in responses ,attention paid to customer needs and Convenience for the customers. Similarly significant differences between expected and perceived service quality was reflected in the HDFC Life Insurance holders as Time taken to complete transaction, Employees are busy, attention paid to customer needs, Convenience for the customers and understanding customer needs. In case of SBI Life Insurance Company, the gaps are significant in layout, Employees are busy, attention paid to customer needs, Convenience for the customers and understanding customer needs.

These gaps indicate that a lot needs to be done by the insurance companied to meet the service expectationsof the customers. Taking regular feedbacks for identifying the gap and removing the gap by providing desired features has to be done on a regular basis.

\section{References}

> Ahuja R,2003," Overcoming adverse selection in Insurance: A developing country Context", Journal of Insurance and Risk Management, pp 94-109, vol.1,Issue2, New Delhi.

> C.N. Krishna Naik, SwapnaBhargaviGantasala and Gantasala V. Prabhakar, 2010, Service Quality (Servqual) and its Effect on Customer Satisfaction in Retailing, Volume 16, Number 2 (2010)

> David Yap, Greg Timbrell, Guy G. Gable, Taizan Chan ,2007, Towards Global Service Quality Dimensions: an Exploration of Commonality in Service Quality Measurement across IndusIndustries, http://www.acis2007.usq.edu.au/assets/papers/150.pdf

$>$ Erdogan H. Ekiz and Ali Bavik ,2008, Scale Development Process: Service Quality in Car Rental Services, http://www.ejbrm.com/vol6/v6-i2/EkizAndBavik.pdf

> Jos Van Iwaarden and Ton Van der Wiele, 2007, A Study on the Applicability of Servqual Dimensions of Web Sites, http://papers.ssrn.com/sol3/papers.cfm?abstract_id=371006

> Jiang, James J.; Klein, Gary; Crampton, Suzanne M ,2000, A Note On SERVQUAL Reliability And Validity In Information System Service Quality Measurement, http://business.clemson.edu/ISE/html/a_note_on_servqual_reliability.html

$>$ Leugenia Ham and Steven Hayduk ,2004, Gaining Competitive Advantages: Analyzing the Gap betweenExpectations and Perceptions of Service Quality, http://www.springerlink.com/content/n07188778522x236/

$>$ MaiveSuuroja, 2003, Sevice Quality- Main Conceptualizations and Critique, http://papers.ssrn.com/sol3/papers.cfm?abstract_id=486947

> Mohammed Alamgir and Mohammed Shamuddoha, 2004, Service Quality Dimensions: A Conceptual Analysis, http://papers.ssrn.com/sol3/papers.cfm?abstract_id=1320144

$>$ Martina Eckardt and SolvigRathke , 2008, The Quality of Insurance Intermediary Services - Empirical Evidence for Germany, http://papers.ssrn.com/sol3/papers.cfm?abstract_id=1272102

> Niveen El Saghier, Demyana Nathan,2013, Service Quality Dimensions and Customers' Satisfactions of Banks in Egypt, Proceedings of 20th International Business Research Conference 4 - 5 April 2013, Dubai, UAE, ISBN: 978-1922069-22-1

$>$ Pathak,J.andDhar ,2003, Role of Non Banking Finance companies in insurance sector: Challenges and opportunities ,Journal of Insurance and Risk management , pp 117-128,Vol.1 issue 02

$>$ Pandelis Zisis , Alexandros Garefalakis and Nikolaos Sariannidis Measurement in the Service Quality Concept: The Case of a Greek Service Organization, http://papers.ssrn.com/sol3/papers.cfm?abstract_id=1359926

$>$ Rossano Giandomenico,2006, Assest Liability Management in Insurance Company, http://papers.ssrn.com/sol3/papers.cfm?abstract_id=907480

$>$ Rainer Gob, Christopher McCollin and Maria Fernanda Ramalhoto ,2007, Ordinal Methodology in the Analysis of Likert Scales, http://www.springerlink.com/content/a149kn36176g1612/ 
$>$ Sonia Chawla and Fulbag Singh ,2008, Service quality perceptions of Life Insurance Policy holders in Northern India: Pre-Privatization vs. Post -privatization, http://papers.ssrn.com/sol3/papers.cfm?abstract_id=1303882

$>$ Sunaynakhurana, 2008,Customer Preferences in Life Insurance Industry in india, http://papers.ssrn.com/sol3/papers.cfm?abstract_id=1267155

$>$ Sureshchandar G.S.; Rajendran C.; Anantharaman R.N ,2002, Determinants of customer-perceived service quality: a confirmatory factor analysis http://www.emeraldinsight.com/Insight/viewContentltem.do?contentType=Article\&contentld=855926

$>$ Saif Siddiqui,2009, Indian Life Insurance sector: An Overview, http://papers.ssrn.com/sol3/papers.cfm?abstract_id=1339447

$>$ Tiffany K.P. Lam ,2002, Making Sense of SERVQUAL's Dimensions to the Chinese Customers in Macau , http://www.springerlink.com/content/v057287712r84424/

\section{Service Quality: Questionnaire}

Based on your experience as a customer in a Life Insurance company, please think about the kind of company that would deliver excellent quality of service. Think about the Insurance Company in which you would like to invest. Please show extend to which you think such a Company would possess the feature described by each statement. If you feel a feature is not at all essential for excellent Insurance Company such as the one you have in mind, circle the number 1 . If you feel a feature is absolutely essential for excellent insurance company circle 5. If your feelings are less strong, circle one of the numbers in the middle. There is no right or wrong answers- all we are interested in is the number that truly reflects your feelings regarding Insurance Company that would deliver excellent quality of service.

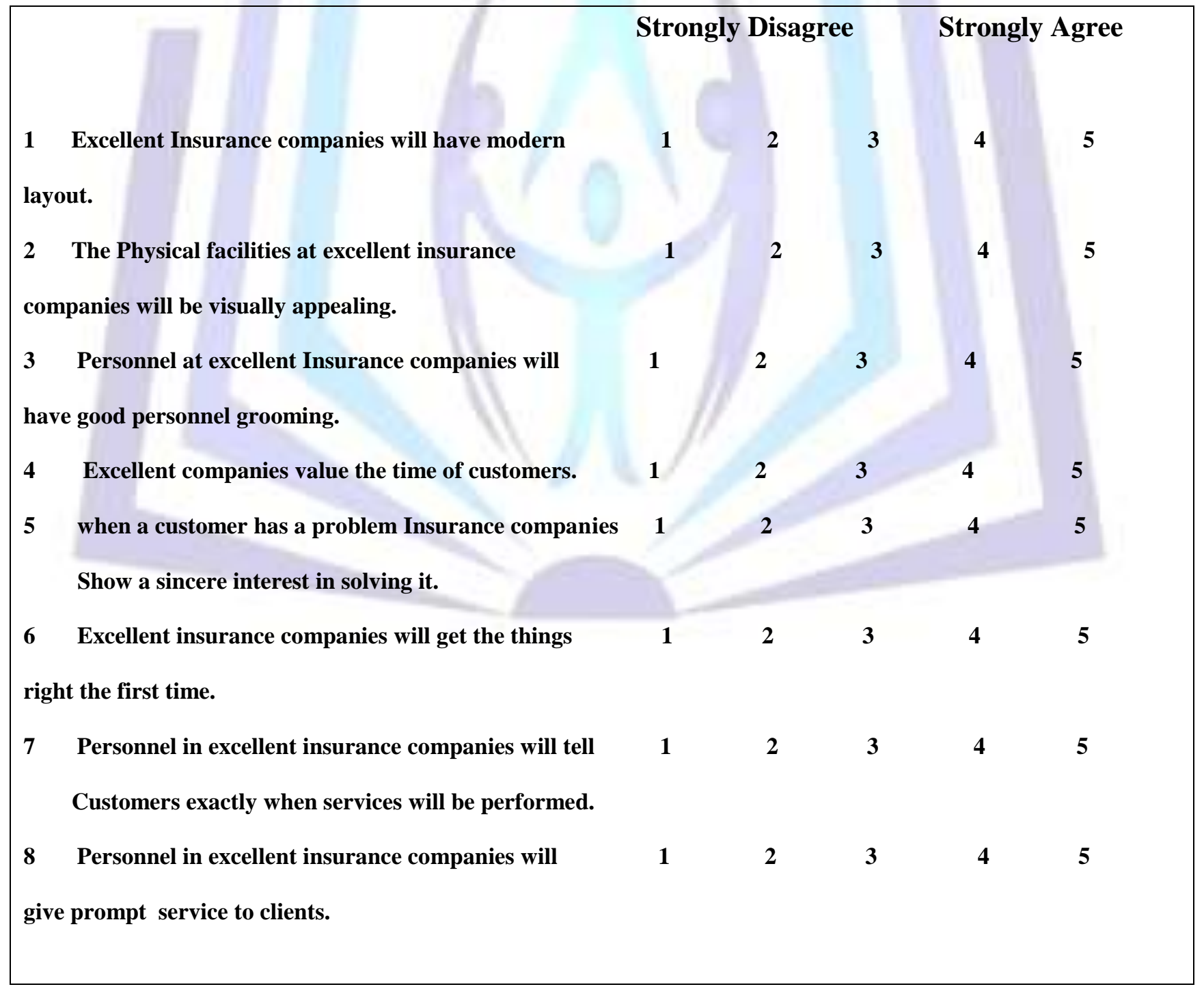


never be too busy to respond to customer request.

10 The behaviour of personnel in excellent insurance companies will instill confidence in customers.

11 Customer of excellent insurance companies will feel safe in their dealing with the insurance companies.

12 Personnel in excellent insurance companies will be constantly courteous with customers.

13 Excellent companies will give customers individual attention.

14 Excellent companies will have operating hours convenient to all their customers.

15 The personnel of excellent insurance companies will understand the specific needs of their customers.
1
Dimension

Statements

Statements

Statements

Statements

Statements

Websites

www.googlescholar.com

http://www.oxfordjournals.org/

www.investopedia.com

http://www.oxfordjournals.org/

www.wikipedia.com

www.ask.com

www.ssrn.com
1- 3
4- 6
7- 9
10- 12
13- 15
Tangibles
Reliability
Responsiveness
Assurance
Empathy 